\title{
Opportunities or barriers? The experiences of disadvantaged older jobseekers participating in training
}

\begin{abstract}
In Australia and other OECD countries, increasing the labour force participation rate of older adults (45-64 years) is seen as a primary strategy to address the current demographic challenges brought about by an ageing population and the retirement of skilled workers. Not all older adults have current workplace skills, yet barriers which include institutional, societal and personal factors, may constrain their participation in training and educational activities to increase their employability. The qualitative, phenomenological study reported here explored, through a series of semi-structured interviews, the experiences of a small group of disadvantaged older jobseekers, as they participated in training and job-seeking activities. Major findings included the disparity between the participants' preferred ways of learning and the delivery modes in their training programs, and that their training activities did not necessarily translate into employment. The findings bring into question the value of training and the effectiveness of current provisions.
\end{abstract}

Key words: barriers, disadvantaged, employability, older, training, jobseekers 


\section{Introduction}

Increasing the labour force participation rate of older adults (45-64 years) is seen as a primary strategy to address the economic and social challenges brought about by an ageing population and the retirement of skilled workers, for Australia and other Organisation for Economic Co-operation and Development (OECD) countries (Deloitte Access Economics, 2012; Productivity Commission, 2013; van Loo, 2011). Increasing or sustaining employability is becoming essential due to the changing requirements of work and workplace practices (Taylor, Jorgensen, \& Watson, 2010). Yet, the ability of older adults to remain employable is at least partially premised on their capacities and interest (Billett, 2011). Their efforts may also be constrained by a range of barriers, which include factors that are institutional, societal and personal (OECD, 2006). If the participation of older adults in training programs does not translate into employment, questions are raised as to its value and the effectiveness of current provisions. This article presents some of the findings of a qualitative study that was conducted, as part of a doctoral thesis, to explore the experiences of a group of older, unemployed, lowskilled adults, who were participating in training programs to increase their employability. Their participation was seen as an instance where a range of interrelating barriers coalesced, and thus provided a context for discussing the key issues.

\section{Demographic trends}

Current demographic trends, such as an ageing population and the retirement of skilled workers, are posing challenges to the economic stability of Australia and other OECD countries. This section outlines those challenges and highlights the economic and social impacts of not addressing them.

\section{Demographic trends}

Australia and other OECD member countries are experiencing considerable demographic challenges, characterised by two trends. Firstly, the population is ageing, due to an increase in longevity and a decline in birth rates (Australian Bureau of Statistics (ABS), 2010; van Loo, 2011). Secondly, the labour force participation rate of older workers is declining, coupled with the retirement of skilled workers (Australian Human Rights Commission (AHRC), 2009). This trend is claimed to be due to the rapid 
social, economic and cultural changes in the last century, as the developed world has shifted from an agricultural to industrial then post-industrial information-based economy (Taylor et al., 2010). So, while there are increasingly greater numbers of older people living and working longer in those countries, there are still not enough people in the upper age group participating in paid employment to offset the economic imbalance brought about by these demographic trends (Deloitte Access Economics, 2012).

\section{Economic and social impacts}

It is predicted that a continuation of the current demographic trends represents a threat to living standards in OECD countries (McLachlan, Gilfallan \& Gordon, 2013; Warren and Oguzoglu, 2010), and, in Australia, would have a negative effect on the national labour market (Productivity Commission, 2013). In terms of economic impacts, the percentage of the population drawing on the social wage would increase, while those contributing to the nation's finances would decrease, placing substantial pressures on public finances (ABS, 2010). Furthermore, these trends could cause a severe decline in Australia and OECD countries' capacities to realise their economic goals, and a projected slowing of the gross domestic product growth (Deloitte Access Economics, 2012; Productivity Commission, 2013). Recently, the economic imperative to increase the employability of older adults has been highlighted, with the decision to raise the age for pension entitlements (Deloitte Access Economics, 2012; The Treasury, 2014).

While these consequences are largely economic, it is claimed there are also those who could be psychologically and socially damaged by these trends. For instance, studies show a link between loss of employment and reduced well-being, and that unemployed people are more likely to suffer from depression and health problems, including psychological disengagement and a lack of motivation (Paul and Moser, 2009; Ranzijn, Carson, Winefield, \& Price, 2006; Winkelmann, 2009). Thus it can be seen that the consequences of not addressing the current demographic trends could have long term and severe economic and social impacts. Due to these potential impacts, the governments of Australia and other OECD countries have deemed that existing policies designed to sustain economic growth need to be aligned to those that incorporate all available labour reserves (OECD, 2006). 


\section{Increasing the labour force participation rate of older adults}

Potentially, older adults are seen as a significant source of additional labour supply, and increasing their labour market participation rate is one strategy to address the current demographic challenges. Another response has been the decision to raise the age for pension entitlements (Deloitte Access Economics, 2012; The Treasury, 2014), which has become common across many countries with advanced industrial economies, such as Australia (Billett, 2011; OECD, 2010a). Whilst increasing the labour force participation rate of older adults is high on the policy agenda of Australia and other OECD countries (Cedefop, 2013a; Fourage \& Schils, 2009; OECD, 2010a), there is a decline in their participation in those countries (van Loo, 2011). Indeed, statistical data from Australia demonstrate that the participation rate of older adults in employment is lower than comparable countries (Deloitte Access Economics, 2012; Johnson, Billett, Dymock, \& Martin, 2013). A core question asks why there are so few older adults in employment.

\section{Participation in training programs}

It is suggested that not all older adults have current skills that readily sustain their employability, and those who are low-skilled are seen as being among the long-term unemployed and most disadvantaged in the modern labour market (Daehlen \& Ure, 2009). Indeed, the increased international trade and large influx of immigrants may have weakened the labour-market position of low-skilled workers in OECD countries (Oesch, 2010). The 'skills obsolescence' of older adults is claimed to be due to the rise in information and communications technology (ICT) (Bang, Cleeman, \& Bramming, 2010; Brinkley, Fauth, Mahdon, \& Theodoropoulou, 2009). So, there is a strong imperative to encourage those adults aged over 45 years, or so-called 'Baby Boomers', who still have the capacity to work, to access and participate in vocational education and training activities to increase their employability (ABS, 2009; Cedefop, 2013b; Karmel, Lu \& Oliver, 2013; Mayhew, Elliott \& Rijkers, 2008). However, their participation in accredited training programs is also low, and continues to decline as those adults age (AHRC, 2009; Department of Employment, Education and Workplace Relations (DEEWR), 2008).

It has been suggested for this cohort that simply increasing their skills may not be sufficient, but that gaining a qualification plays an important role in their obtaining 
employment (Karmel \& Nguyen, 2007), or at least improving their attachment to the labour market (Cedefop, 2013a). Studies have found that labour-market-related gains are greater for those older adults who complete higher-level qualifications and that gaining lower-level qualifications, and that incomplete qualifications may in fact have a negative effect on labour-market-related gains for some older people (Karmel \& Nguyen, 2007). The recognition of prior learning (RPL) process is one way of targeting support for this cohort, by acknowledging previous skills and experience gained over the life course. It is a major policy initiative by the Australian government (Department of Education and Training, (DET), 2011; Misko, 2007), and is seen as being particularly beneficial to people without formal qualifications (Cedefop, 2013a; Cedefop, 2013b; Misko, 2007).

\section{Barriers to participation in training programs}

The low rate of participation by older adults in employment and training is attributed to several interrelated factors and barriers, including those that are: (1) institutional, including financial disincentives, such as welfare benefits, superannuation systems and retirement arrangements; (2) societal sentiments, such as age discrimination, reflected in employer attitudes and practices; and (3) personal or dispositional, such as low selfesteem and a lack of self-confidence (Headey, 2011; OECD, 2006; Temple, Adair, \& Hosseini-Chavoshi, 2011). It is claimed that those factors and barriers are not isolated, but interdependent (Rubenson \& Desjardins, 2009; Temple et al., 2011). Studies have found that existing training programs do not suit the learning needs and preferences of older, low-skilled adults, as they are mostly online (Lundberg \& Marshallsay, 2007; Meyers, Billett, \& Kelly, 2010; Tikkanen, 2009). These conclusions are consistent with the literature in this area concerning the current prevalence of online learning in VET programs (Department of Education, Science \& Training (DEST), 2007; OECD, 2010b).

In acknowledging the range of barriers to participation in training for older adults, it is accepted that these barriers affect older adults in different ways. Those with low education and low skills are more disadvantaged than others (Billett, 2011; Mayhew et al., 2008). Yet those older adults who are under- or unemployed face a more severe challenge to sustain their employability, as they do not have a workplace practice 
environment, and the kinds of access and opportunities to learn 'on-the-job’ (Billett, 2011; Illeris, 2006). Those older adults who are over 55 years, unemployed and lowskilled are called 'disadvantaged older workers’ (Mayhew et al., 2008; McLachlan et al., 2013). That is, they are called 'workers' by the Australian Government, whether they are employed or unemployed, and, if they are seeking employment, are called 'jobseekers' (Australian Government, 2014). For this cohort, it is claimed that there is an accumulation of disadvantages; their original affordances were poor, and this can equate to an inability to engage successfully in training and translate that to employment (Billett, Dymock, Johnson, \& Martin, 2011a; Mayhew \& Rijkers, 2004; OECD, 2006; Tikkanen, 2009).

Considering the economic and social consequences of not addressing the current demographic trends, there is an imperative to reduce the barriers to the participation of older adults in both training and job-seeking activities (The Treasury, 2010). The study that is outlined below set out to investigate the experiences of a small group of disadvantaged older workers, referred to here as ‘disadvantaged older jobseekers'.

\section{Exploring the training experiences of disadvantaged older jobseekers}

A study was conducted that sought to illuminate and elaborate the barriers mentioned above, through an exploration of the experiences of a small (eight) group of disadvantaged older jobseekers as they participated in training and job-seeking activities. These activities were seen as an instance where the factors and barriers coalesced and as such, provided an appropriate context in which to illuminate and elaborate this phenomenon.

\section{Methodology}

The study utilised a qualitative orientation because of its capacity to obtain a detailed understanding of an issue, to empower individuals to share their stories (Miles \& Huberman, 1994), and to minimise the power relationships that often exist between a researcher and the participants in a study (Merriam, 1998). A phenomenological approach was considered the most appropriate and suitable for the nature of the inquiry, as it can secure insightful, personal accounts (Creswell, 2007; Groenewald, 2004) and when the question has 'both social meaning and personal significance' (Moustakas, 
1994, p. 103). The use of semi-structured interviews organised around a set of predetermined questions was selected as a method of data gathering, as it enabled a comprehensive exploration of the subjectivities of the small group of participants, as suggested by Creswell (2007) and Whiting (2008). Interviews were selected as the method of data gathering, as they are an appropriate choice when employing a phenomenological approach, and when investigating the subjectivities of a small group of participants (Creswell, 2007; Whiting, 2008). The data-gathering process involved a series of five one-on-one, face-to-face semi-structured interviews with the eight participants, over a five to eight month period, using pre-prepared interview protocols. However, there was an opportunity to ask other questions that emerged from the dialogue, which were followed by probes or a prompt, to obtain more in-depth answers or to follow up on points of interest.

The primary research question was: What are the experiences of disadvantaged older job-seekers participating in training and job-seeking activities to increase their employability?

\section{The participants}

The participants were selected through purposive sampling: a procedure deemed appropriate when a study requires the selection of 'unique cases that are especially informative' (Neuman, 2006, p. 222), as was the case here. They consisted of eight adults - five females and three males - from a variety of backgrounds, who were undertaking a range of vocational qualifications to increase their employability. The participants were over 55 years of age, low-skilled and under- or unemployed. Despite their varied backgrounds, the participants had three historical factors in common that seemed to predispose them to a marginalised position in the contemporary labour market. First, they had an education history that was limited by the societal expectations and historical events in the era in which they were born. Second, they had only attained a low-skills base, and were therefore 'perilously' placed in the labour market. Third, they had work histories that were unsteady, with part-time or casual work, and included long periods of unemployment, often due to family responsibilities and obligations. The participants all resided in an Australian capital city. All the names used are pseudonyms, and were chosen by the participants. 


\section{The training activities and experiences of disadvantaged older jobseekers}

The study was conducted as part of the requirements for a doctoral thesis, and produced a vast amount of data, addressing a range of issues. However, the findings presented here pertain to the kinds of training activities the participants were undertaking, their personal responses to experiences during training activities, and their employment outcomes.

\section{Training activities}

The eight participants were involved in a variety of training activities, and during the period of interviews, two participants were undertaking two programs. Each participant was at a different stage of completion of their training programs. Table 1 shows the training activities of the participants. A Certificate I, II or III is considered a low level vocational certificate; a Certificate IV or Diploma is considered a high level vocational certificate, and a Bachelor is an undergraduate degree at university. The left-hand column shows the name of the participant ('M' stands for male participant, 'F' stands for female participant), the middle column lists any previous training they had completed, and the right-hand column lists the training they were undertaking during the series of interviews.

Table 1. Training activities (insert near here)

From Table 1 it can be seen that six participants had previously undertaking formal training, with four of them obtaining low level vocational certificates. By contrast, Linda had obtained a university degree, but, at the time of the interview, that was 23 years ago. Two participants had previously had no formal training. In their current activities, five participants were undertaking government-funded training programs as part of their obligations under the 'Newstart Allowance Scheme', that is, to qualify as recipients of unemployment benefits (Department of Human Services, 2014). Kelvin was attempting to obtain a Diploma of Community Development through the RPL process. Tamara had undertaken a medical receptionist course, which was formal but did not lead to a qualification. She was also undertaking a Diploma of Shiatsu, as 
she was interested in alternative medical practices. Dan was the only participant undertaking a university degree.

\section{Purposes for undertaking training}

The participants had various purposes for participating in training, yet there was general agreement that to compete in the contemporary labour market, their skills needed to be upgraded, and that having a qualification was advantageous to their efforts. This finding is consistent with literature in the field from authors such as Karmel and Nguyen (2007) and O’Keefe, Crase, and Dollery (2007). In Table 2, the left-hand column shows the participants' name, the middle column shows their purposes for undertaking training, and the left-hand column shows their corresponding experiences during that training program.

Table 2. Purposes for undertaking training and experiences while training (insert near here)

In Table 2, it can be seen that there were distinct institutional, that is, external factors that motivated five of the participants, i.e. to appease government obligations, while Kelvin, Dan and Tamara had more personal factors that motivated their participation in their various training courses. Tamara was pursuing a qualification in an area of interest to her. Both Kelvin and Dan acknowledged that they had the knowledge, skills and experience needed to maintain their employment opportunities, but both believed the further qualifications would increase their income, and give them the confidence to apply for senior, management positions. Dan stated: 'Essentially the degree was a progression to go up in the pay scale, but with the opportunity to have a choice' and that 'I'm deeply sorry I didn't do it sooner.' This sentiment refers to his regret when his chances of attending university as a young man were denied due to external circumstances.

Conversely, the data indicated that those participants who were obliged to participate in government-funded training viewed their mutual obligations negatively, using words such as 'pressure' and 'coercion' to describe the government approach to their participation in pre-specified training activities. They reported that they were given limited opportunities to make their own decisions concerning participation. For 
example, Corinne stated that she enjoyed some aspects of her training course, but she felt 'pressurised' to participate, and that the social security system did not seem to be 'pressurising' younger people as much as older adults. The female participants, in particular, used words such as 'anger' and 'frustration' when describing expectations that they continue working and undertaking training at their age.

\section{Experiences while training}

As well as their diverse motivations for undertaking training, there was a corresponding diversity in experiences. For four of the participants, there were reports of feeling “daunted” and lacking in confidence, as some had not completed any formal training for 40 years. Expressing her apprehension, Suzanne acknowledged that: 'I was petrified at starting, you know, the course, because, you know, it had been so long.' Conversely, four of the participants expressed enthusiasm for learning at a later age. As an example of this enthusiasm, Ellie-May commented: 'It's going to give me more confidence. I've always known what has to be done and how to get around a problem. I've just never had the qualifications.' However, some of the participants reported they had negative experiences in the classroom learning environment. For example, Ellie-May, who was attending a government-funded training course, stated: 'I don't feel to ask questions sometimes, and if you don't ask questions, you don't find out anything. I felt like such a fool; I just wanted to leave.' Tamara's experiences were similar, despite not participating in a funded training program, and she commented: 'Sometimes I had questions I didn't bother to ask, because I've got a feeling that I don't want to be seen as the fool, or the one who didn't understand the question.' Noah, who identified as an Indigenous Australian and was Very Long-term Unemployed, reported a lack of self-confidence during his training programs. He experienced difficulties that he attributed to issues arising from his cultural background and claimed that some classroom environments were not 'culturally aware'. These findings indicate that the participants' ability to learn was constrained by their dispositional reactions to the learning environment.

It is also possible to identify a connection between the five participants who were participating in government-funded training and their reports of frustrations or difficulties. The data revealed that the primary source of those negative experiences was the disparity between the participants' preferred way of learning and the current mode of 
delivery in their training courses, with six participants reporting they had low levels of computer literacy. Their experiences are similar to others with low computer literacy, who, it is claimed, are at a distinct disadvantage in the online learning environments commonly utilised in VET, and in the contemporary labour market (DEEWR, 2011; Dickinson, Eisma, \& Gregor, 2011). It is suggested that this disparity was one of the key barriers to their engagement in, and completion of, those courses. For example, Linda, who was 62 years old during the interview process, stated: 'I'm a technophobe!' Another example is Ellie-May, who, regarding the amount of online work required for her course, claimed: 'I’m finding it very hard. If you're computer literate, you can breeze through most of these courses; if you're like me, and most people in my age group, then, Nah!' Similarly, Noah stated in each interview that his computer skills were very low, and that this impacted directly on his confidence and ability to study.

Four participants commented that improving their computer skills would greatly assist them and other older jobseekers in upgrading their workplace skills. As Linda remarked: 'Then all of the other skills I've got, that are hiding behind my lack of technology, they could escape.' In contrast, Kelvin and Dan reported their computer literacy abilities were sufficient for their work and study needs. However, they both conceded that a totally online course would be very challenging for those aged over 55 years. Indeed, five participants reported there was a lack of appropriate computer courses for people their age, and they all agreed that such a course would be one way to support older jobseekers in upgrading their workplace skills. Corinne reported that she inquired about attending a government-funded computer course to increase her skills, but stated: 'No, they [social security agency] didn’t offer that, a decent computer course.' Their responses are consistent with findings in comparable studies which criticise the nature of support that government training and employment agencies are providing, and link them to several of the key barriers to participation in training for older jobseekers (DEST, 2004; Illeris, 2006; Temple et al., 2011).

\section{Employment outcomes}

To be a part of this study, participants had to be either under- or unemployed. However, despite three participants reporting they were undertaking training programs for personal motivations, they all conceded that the main purpose was to increase their 
employability. Table 3 shows the employment status of the participants at the first and then at the final interview. The left-hand column shows the name of the participant, the second column shows their age (three participants had birthdays during the series of interviews), the next column shows their employment status at the first interview and the right-hand column shows their employment status at the end of the series of interviews, approximately five to eight months later.

\section{Table 3. Employment status at Interview 1 and at Interview 5 (insert near here)}

From Table 3 it can be seen that, by the end of the series of interviews, none of the participants were employed full-time, and indeed, two had become unemployed. Both Kelvin and Suzanne reported that they were employed under a Wage Subsidy Scheme, whereby the Australian Government offers financial incentives to employers who employ those aged 50 years and over (DEEWR, 2010). Kelvin was employed casually for a six-month period and once this had ended, his employer reduced his casual work from 22 hours to 15 hours. After the three-month period that Suzanne was employed under this Scheme, she was made redundant. Table 3 shows that Corinne was the only participant who was in a better position at the last interview than at the first, although her future employment was dependent on a government contract being renewed. Thus, for this group, by the end of the fifth interview, that is, up to eight months later, there was either no change to their employment status, or it had worsened.

All of the participants expressed the belief that gaining employment would both require and grant them self-confidence. The data revealed that becoming unemployed, or remaining unemployed, impacted directly on their sense of self and identity. This finding is consistent with similar studies that found perceived low human and social capital impacts negatively on belief in individual learning ability or trainability (Billett et al., 2011a Tikkanen, 2009). For example, Tamara was deemed Very Long-term Unemployed, and even after undertaking a training program, stated: 'But I'm terrified to look for a job - haven’t done a thing! I just feel so inadequate.'

For some of the participants, being unemployed led to reports of dispositional barriers and psychological issues. For example, Dan attributed concerns about his financial situation during his unemployment to psychological ill-health and he sought medical treatment for depression. He reported being frustrated while having to deal with 
what he saw as 'a lack of control and power'. He claimed that he had 'always had a strong sense of self and self-worth' which had 'taken a bit of a battering since I've been unemployed'. Dan discontinued his studies to concentrate on obtaining employment. Another example is Linda, who expressed some anger about her situation, stating: 'I've done all the right stuff [training and job-seeking activities], and I still don’t have a job.' Consistent with similar studies (Paul \& Moser, 2009; Ranzijn et al., 2006; Winkelmann, 2009), all of the participants reporting negative emotions, such as lack of selfconfidence, anger and depression. Their continued disadvantaged status lowered their self-esteem, and consequently, their self-efficacy, a link that has been made by Bandura (2006).

The value of undertaking training to increase employability

In consideration of their negative employment outcomes, at least in the short term, the participants were asked to consider the value of participating in training activities, in terms of both the intrinsic, or personal value, and the outcomes for employment. Interestingly, the genders were divided on the value of training as a means of increasing employability. Although the female participants reported that they enjoyed some aspects of participating in training courses, they were disparaging about the possibility of gaining employment after their completion. For example, Corinne did not gain employment until the time of the final interview, so, during the first four interviews, she expressed her frustration that participating in a government-funded training course had not lead to any employment. She claimed: 'You've got the certificate, but it's just a piece of paper, and at the end of the day, it's really not doing you any good, not that I can see.' Similarly, when Suzanne was asked whether she thought her training course would lead to employment, she asked rhetorically: 'Seriously? No. How many older, aged people do you see being employed? What are you doing the training course for, if there's no achievement at the other end?' However, Corinne observed that 'The course was definitely not aimed at getting older people into work.' Ellie-May's comments were similar, and she suggested that, if the government wanted older people to participate in more training, they should subsidise more courses.

Linda also expressed her anger that, because she was receiving unemployment benefits, she had to undertake training and claimed: 'They [the government] have their 
own agenda, it's as simple as that! And if they've got a different agenda, why am I being punished?' Similarly, Tamara claimed that, although future learning plans were for her own personal benefit, she believed there was pressure on her to participate in activities to upskill. She admitted that: 'I get angry about that, because I think that's a cop-out by the government. I think they're getting older people to work, so they don't have to pay them the pension.'

Conversely, the male participants reported that they highly valued undertaking any training as both a means of increasing employability and for personal benefits. For instance, Dan stated: 'I think the value of employment is that it shows that someone else believes in you, as well as you.' Kelvin observed: 'I think it's good for older people to go to training and go to classes. It keeps their brains working.' Noah was also in agreement that older adults needed to be trained, stating: 'Before someone should be employed, they should get the skills, if it's not too stressful. But if they're not comfortable, then I don't think they should be forced.'

In sum, although most of the participants agreed that participating in training activities was beneficial in some ways, their responses indicate a range of interrelated barriers constrained their efforts, and were not addressed by the provisions available to them.

\section{Providing training to increase the employability of disadvantaged older jobseekers}

Whist there are assumptions that education and training will improve the workplace situation of older adults (Daehlen \& Ure, 2009; Karmel \& Nguyen, 2007; Mayhew et al., 2008), it is claimed that existing programs are inappropriate or inaccessible, and are not well-adapted to individual learning needs (Billett, 2011; Billett et al., 2011b; Rubenson \& Desjardins, 2009). The findings indicate that these claims are particularly relevant to the participants in the study discussed here. In particular, the disparity between their preferred way of learning and the prevalence of online learning was shown to be a contributor of barriers to participation in both training and job-seeking activities for this group. From this finding, it can be said that their learning needs and preferences were not taken into account, resulting in experiences of a lack of selfconfidence and low self-esteem, consistent with the literature in the field (Bandura, 2006; Billett et al., 2011a; Tikkanen, 2009). In this way, external, or institutional, 
barriers impacted on, or exacerbated personal or dispositional, barriers. Therefore, it can be seen that attempting to understand the implications of the barriers faced by older jobseekers, by only focusing on institutional factors, is unproductive, as those barriers are interdependent and interrelated.

The provision of government-funded training appeared to produce a barrier for some of the participants, rather than an opportunity. It is contended that, as a single response to the need for 'up-skilling', this provision was ineffective because: (1) it was not linked to work experience; (2) it was not linked to employment; (3) there were obligations and pressure associated with participation; (4) most training programs were online, which was not their preferred way of learning, nor accessible to all the participants; and (5) it was not specifically targeted at this age group. Many of them were discouraged, and questions remain as to the value of providing training without providing links to employment.

Although the RPL process is seen as beneficial for older adults without formal qualifications, with their history of inconstant low-skilled work, most of the study participants did not have documentation to prove their knowledge, skills or experience. They reported that requirement formed an insurmountable barrier, and it is advanced here that the process may need to be adjusted to more efficiently align with the needs of disadvantaged older jobseekers. Thus, it is proposed that targeted training for this cohort needs to: (1) be appropriate for their age group; (2) be delivered in a way that is appropriate for their level of computer literacy; (3) include content that increases individual self-esteem and self-efficacy; (4) be aligned with workplace practice and employment; and (5) utilise the recognition of prior learning processes more effectively, taking into account their lack of documentation. Therefore, there is an imperative to design strategies to encourage and support others similarly disadvantaged to participate in the kinds of activities that increase their employability, albeit in personally-defined ways.

Through an exploration of the experiences of a group of disadvantaged older jobseekers, this study has highlighted a misalignment between the negative employment outcomes of the participants and existing measures designed to increase their employability. The findings of this study cannot be generalised. However, if the experiences of this group of disadvantaged older jobseekers are extrapolated to the 
population, it is held that this misalignment stands as illustrative of a major barrier to the achievement of government goals. Their situation reinforces the argument that, over the long term, there are profound and ongoing consequences for this cohort, who, it is claimed, are sorely placed in the contemporary labour market (Cedefop, 2013a).

\section{Implications for policy, practice and research}

Since 2000, the potential of increasing the labour force participation of older adults has gathered momentum in the public policy arena and, in Australia, a variety of strategies and initiatives have been implemented to achieve that goal (DEEWR, 2008). It has been suggested (Lundberg \& Marshallsay, 2007; The Treasury, 2010) that a thorough understanding of all the relevant factors that both produce barriers and create opportunities for older adults to participate in training, particularly those most vulnerable, is a key imperative in the development of policies and strategies.

\section{Implications for policy}

According to Billett and van Woerkom (2006), the connection between national strategies and provisions from VET is policy design. Rubenson and Desjardins (2009) suggest that teaching strategies should focus on what drives individual intentionality and interest in learning activities, encompass individual learning needs, and motivate participants to take up new challenges and master new skills. Indeed, a key role for public policy would be to 'foster governance and institutional structures that seek to identify and resolve misaligned incentives among stakeholders' (Rubenson \& Desjardins, 2013, p. 268). Given the strong economic rationale for increasing the labour force participation rate of older adults (McLachlan et al., 2013; Warren \& Oguzoglu, 2010), there appears to be a need for governmental policies and provisions that address their particular range of barriers.

\section{Implications for practice}

The literature consistently reports on barriers for older adults to participate in training (Temple et al., 2011), yet, despite policies and programs aimed at addressing those barriers, it is acknowledged that goal remains unaddressed (Cedefop, 2013c; Johnson et al., 2013). It is claimed that, in order to improve both participation and engagement in 
training programs, individual learning and support needs should be taken into consideration with targeted training programs (Meyers et al., 2010; The Treasury, 2010). It is suggested that, due to historical factors, one of the important barriers to upgrading older adults' skills is that they themselves do not always see the benefits of investing in their knowledge, skills and competences (Cedefop, 2013c). Therefore, it is seen as important to provide encouragement and support for training or upgrading of their skills, and encourage them to be aware of the full range of benefits training can bring. Those include not only for securing a job, but also personal fulfilment (Daehlen \& Ure, 2009; van Loo, 2011). Thus, it is suggested that work-related and integrated forms of learning which are closely linked to daily work and previous professional and learning experience are particularly suitable for unemployed older adults (Cedefop, 2013b), as unemployed older adults face a more severe challenge to sustain their employability, as they do not have a workplace practice environment (Billett, 2011). It is also suggested that increasing the self-esteem of these jobseekers is a major part of the key to increasing their employability (Kanfer \& Ackerman, 2004; Pool \& Sewell, 2007). In particular, for those older adults who may be unemployed and disabled, it has been suggested (Riach \& Loretto, 2009) that understanding the processes of how they construct and negotiate their working identities could help to illuminate the range of barriers constraining them.

\section{Implications for research}

Given the predications of negative economic and social impacts should demographic trends not be addressed, the conclusions and implications set out above emphasise the central role of research into these issues. Previous research into issues associated with the training participation of older jobseekers has mostly been conducted in Australia by means of large-scale surveys, such as those conducted by the NCVER (Karmel \& Nguyen, 2007) and DEEWR (2008). However, it has been claimed that in large-scale surveys in both Australia and Europe, issues such as employment and training are researched 'on behalf of older jobseekers' (Tikkanen, 2009, p. 221), and that the perspectives of older adults themselves, that is, those that are in their 'voice', have been largely missing (Lundberg \& Marshallsay, 2007; Stuart \& Perrett, 2006; Tikkanen, 2009). From these claims, it is contended that the amount of empirical literature and 
research that focuses specifically on considerations of how older jobseekers might engage with educational programs and workplaces is scarce. Indeed, it is claimed that the outcomes of qualitative research studies that do not focus merely on the negative aspects of older jobseekers and their competence, are still lacking (Ranzijn et al., 2006; Tikkanen, 2009). It was this gap in the literature that prompted the investigation reported here. However, the findings and conclusions indicate the need for further research, to understand the barriers facing disadvantaged older jobseekers, from their own perspectives. Given the key role older adults can play in offsetting an economic and social crisis, it is suggested research into these issues be conducted in a timely manner. 


\section{References}

Australian Bureau of Statistics. (2009). Australian social trends, September 2009. Report, Canberra, Australia: Author.

Australian Bureau of Statistics. (2010). Australian social trends, September 2010. Older people and the labour market. Report. Canberra, Australia: Author.

Australian Government. (2014). Jobseekers. Retrieved from http://australia.gov.au/people/jobseekers

Australian Human Rights Commission. (2009). Experience Works: Report highlights our hidden age-discrimination problem. Retrieved from http://dwa.atsiphj.com.au

Bandura, A. (2006). Toward a psychology of human agency. Perspectives on Psychological Science, 1(2), 164-180.

Bang, A., Cleeman, C. M., \& Bramming, P. (2010). How to create business value in the knowledge economy: Accelerating thoughts of Peter F. Drucker. Management Decision, 48(4), 616-627.

Billett, S. R. (2011). Older workers, employability and tertiary education and training. In Griffin T. \& Beddie, F. (Eds.). Older workers: Research readings, (pp.97-109). Adelaide, Australia: National Centre for Vocational Education Research.

Billett, S. R., Dymock, D., Johnson, G., \& Martin, G. (2011a). Overcoming the paradox of employers' views about older workers. International Journal of Human Resource Development, 22(6), 1248-1261.

Billett, S. R., Dymock, D., Johnson, G., \& Martin, G. (2011b). Last resort employees: Older workers' perceptions of workplace discrimination. Human Resource Development International, 14(4), 375-389.

Billett, S. R., \& van Woerkom, M. (2006). Older workers and learning through work: Agency, intentionality and critical reflection. In T. Tikkanen \& B. Nyhan (Eds.) Promoting lifelong learning for older workers, (pp. 177-189). Luxembourg, Luxembourg: CEDEFOP.

Brinkley, I., Fauth, R., Mahdon, M., \& Theodoropoulou, S. (2009). Knowledge workers and knowledge work: A knowledge economy programme report. London, UK: The Work Foundation.

Cedefop. (2013a). Empowering vulnerable adults to tackle labour market challenges. Retrieved from http://www.cedefop.europa.eu/EN/Files/4122_en.pdf

Cedefop. (2013b). Return to learning, return to work. Retrieved from http://www.cedefop.europa.eu/EN/Files/9082_en.pdf

Cedefop. (2013b). Silver workers - golden opportunities. Retrieved from http://www.cedefop.europa.eu/EN/Files/9077_en.pdf

Creswell, J. W. (2007). Qualitative inquiry \& research design: Choosing among five approaches ( $2^{\text {nd }}$ Edition). Thousand Oaks, CA: Sage Publications.

Dæhlen, M., \& Ure, O. (2009). Low skilled adults in formal continuing education: Does their motivation differ from other learners? International Journal of Lifelong Education, 28(5), 661-674.

Deloitte Access Economics. (2012). Increasing participation among older workers: The grey army advances. Canberra, Australia: Author.

Department of Education and Training. (2011). Recognition of prior learning and credit transfer. Retrieved from http://www.training.qld.gov.au/information/rpl.html

Department of Education, Science and Training. (2004). Furthering success: education, training and employment transitions for disadvantaged older workers. Canberra, 
Australia: Research Analysis and Evaluation Group.

Department of Education, Science and Training. (2007). 2007 E-learning benchmarking project: Final report. Canberra, Australia: Australian Flexible Learning Framework, Department of Education, Science and Training \& I. \& J. Management Services.

Department of Employment, Education and Workplace Relations. (2008). Australian vocational, education and training statistics: Employer use and views of the VET system: 2007 summary. Adelaide, Australia: National Centre for Vocational Education Research.

Department of Employment, Education and Workplace Relations. (2010). Productive Ageing Package. Retrieved from https://www.nesa.com.au/informationservices/news/2010/2/1/productive-ageing-package.aspx

Department of Employment, Education and Workplace Relations. (2011). 2011 Elearning benchmarking project: Final report. Canberra, Australia: Australian Flexible Learning Framework, Department of Employment, Education and Workplace Relations \& I. \& J. Management Services.

Department of Human Services. (2014). Payments for job seekers. Retrieved from http://www.humanservices.gov.au/customer/subjects/payments-for-job-seekers

Dickinson, A., Eisma, R., \& Gregor, P. (2011). The barriers that older novices encounter to computer use. Universal Access in the Information Society, 10(3), 261-266.

Fourage, D., \& Schils, T. (2009). The effect of early retirement incentives on the training participation of older workers. Labour, 23, 85-109.

Groenewald, T. (2004). A phenomenological research design illustrated. International Journal of Qualitative Methods, 3(1), 1-25.

Headey, B. (2011). Economics of population ageing: Australia may not have a labour supply problem, but recent superannuation reforms have not helped. In T. Griffin \& F. Beddie (Eds.). Older workers: Research readings (pp. 67-80). Adelaide, Australia: National Centre for Vocational Education Research.

Illeris, K. (2006). Lifelong learning and the low-skilled. International Journal of Lifelong Education, 25(1), 15-28.

Johnson, G., Billett, S. R., Dymock, D., \& Martin, G. (2013). The discursive (re)positioning of older workers in Australian recruitment policy reform: An exemplary analysis of written and visual narratives. Equality, Diversity and Inclusion: An International Journal, 32(1), 4-21.

Kanfer, R., \& Ackerman, P. (2004). Aging, adult development, and work motivation. Academy of Management Review, 29(3), 440-458.

Karmel, T., Lu, T., \& Oliver, D. (2013). Starting out in low-skill jobs. Adelaide, Australia: National Centre for Vocational Education Research.

Karmel, T., \& Nguyen, N. (2007). The value of completing a VET qualification. Report. Adelaide, Australia: National Centre for Vocational Education Research.

Lundberg, D., \& Marshallsay, Z. (2007). Older workers'perspectives on training and retention of older workers: support document - South Australian construction industry study. Report. Adelaide, Australia: National Centre for Vocational Education Research.

McLachlan, R., Gilfillan, G. \& Gordon, J. (2013). Deep and persistent disadvantage in Australia. Productivity Commission Staff Working Paper. Canberra, Australia: Productivity Commission.

Mayhew, K., Elliott, M., \& Rijkers, B. (2008). Upskilling older workers. Ageing 
Horizons, 8, 13-21.

Mayhew, K., \& Rijkers, B. (2004). How to improve the human capital of older workers or the sad tale of the magic bullet. [Paper prepared for the joint EC-OECD

Seminar of Human Capital and Labour Market Performance]. Paris, France: OECD.

Merriam, S. B. (1998). Qualitative research and case-study applications in education. San Francisco, CA: Jossey Bass.

Meyers, R., Billett, S. R., \& Kelly, A. (2010). Mature-aged workers' learning needs and motivations for participation in training programs. International Journal of Training Research, 8(2), 116-127.

Miles, M. B., \& Huberman, A. M. (1994). Qualitative data analysis. (2 ${ }^{\text {nd }}$ Edition). Thousand Oaks, CA: Sage Publications.

Misko, J. (2007). The recognition of non-formal and informal learning in Australia: Country background report prepared for the OECD activity on recognition of nonformal and informal learning. Canberra, Australia: Department of Education, Science and Training.

Moustakas, C. A. (1994). Phenomenological research methods. Thousand Oaks, CA: Sage Publications.

Neuman, W. L. (2006). Social research methods: Qualitative and quantitative approaches. (6 ${ }^{\text {th }}$ Edition). Boston, MA: Pearson Education, Inc.

Oesch, D. (2010). What explains high unemployment among low-skilled workers? Evidence from 21 OECD countries. European Journal of Industrial Relations, 16(1), 39-55.

O'Keefe, S., Crase, L., \& Dollery, B. (2007). Does the reality of workplace training match the theory? An analysis of public sector employees' training decisions. International Journal of Training Research, 5(2), 41-54.

Organisation for Economic Co-operation and Development. (2006). Live longer, work longer: A synthesis report. Retrieved from

www.oecd.org/dataoecd/32/50/36218997.pdf

Organisation for Economic Co-operation and Development. (2010a). Trends shaping education 2010. Paris, France: OECD.

Organisation for Economic Co-operation and Development. (2010b). Country memo as a background paper for the OECD Disability Review, November 2007: The OECD "Sickness, Disability and Work" project. Paris, France: OECD.

Paul, K. I., \& Moser, K. (2009). Unemployment impairs mental health: Meta-analyses. Journal of Vocational Behavior, 74(3), 264-282.

Pool, L. D., \& Sewell, P. (2007). The key to employability: Developing a practical model of graduate employability. Education + Training, 49(4), 277-289.

Productivity Commission. (2013). An ageing Australia: Preparing for the future: Productivity Commission Research Paper Overview. Canberra, Australia: Author.

Ranzijn, R., Carson, E., Winefield, A. H., \& Price, D. (2006). On the scrap-heap at 45: The human impact of mature-aged unemployment. Journal of Occupational and Organisational Psychology, 79(3), 467-479.

Riach, K., \& Loretto, W. (2009). Identity, work and the 'unemployed' worker; age, disability and the lived experience of the older unemployed. Work, Employment and Society, 23(1), 102-119.

Rubenson, K., \& Desjardins, R. (2009). The impact of welfare state regimes on barriers to participation in adult education: A bounded agency model. Adult Education 
Quarterly, 59(3), 187-207.

Rubenson, K., \& Desjardins, R. (2013). Participation patterns in adult education: The role of institutions and public policy frameworks in resolving coordination problems. European Journal of Education, 48(2), 262-280.

Stuart, M., \& Perrett, R. (2006). Learning in a restructured industrial environment: Older workers 'displaced' from the British steel sector. In T. Tikkanen \& B. Nyhan (Eds.), Promoting lifelong learning for older workers (pp. 224-239). Luxembourg, Luxembourg: CEDEFOP.

Taylor, P., Jorgensen, B., \& Watson, E. (2010). Population ageing in a globalising labour market: Implications for older workers. China Journal of Social Work, 3(2-3), 259-272.

Temple, J., Adair, T., \& Hosseini-Chavoshi, M. (2011). Ageing and the barriers to mature-age labour force participation in Australia. Canberra, Australia: Department of Education, Employment and Workplace Relations.

The Treasury. (2010). The 2010 Intergenerational Report. Retrieved from www.treasury.gov.au/igr/igr2010/report/html/01-Executive_Summary.asp The Treasury. (2014). The 2014-15 budget [Media release]. Retrieved from http://jbh.ministers.treasury.gov.au/media-release/021-2014/

Tikkanen, T. (2009). The learning society as a greying society: perspectives for older workers and lifelong learning. In Cedefop (Ed): Modernising vocational education and training: $4^{\text {th }}$ report on vocational training research: background report. Volume 2, 195-238. Luxembourg, Luxembourg: CEDEFOP.

Van Loo, J. (2011). Making the most of mature minds: Issues, trends and challenges in making active ageing a reality. In T. Griffin \& F. Beddie (Eds.), Older workers: Research readings (pp. 13-20). Adelaide, Australia: National Centre for Vocational Education Research.

Warren, D., \& Oguzoglu, U. (2010). Retirement in Australia: A closer look at the financial incentives. Australian Economic Review, 43(4), 357-375.

Whiting, L. S. (2008). Semi-structured interviews: Guidance for novice researchers. Nursing Standard, 22(23), 35-40.

Winkelmann, R. (2009). Unemployment, social capital, and subjective well-being. Journal of Happiness Studies, 10(4), 421-430. 


\section{Tables}

Table 1. Training activities

\begin{tabular}{|c|c|c|}
\hline Name & Previous training & Current training \\
\hline Corinne (F) & $\begin{array}{l}\text { Certificate III in Education } \\
\text { Support }\end{array}$ & $\begin{array}{l}\text { Certificate III in Community } \\
\text { Services }\end{array}$ \\
\hline Kelvin (M) & Nil & $\begin{array}{l}\text { Diploma of Community } \\
\text { Development (RPL) }\end{array}$ \\
\hline Noah (M) & $\begin{array}{l}\text { Certificate II in Transport and } \\
\text { Logistics }\end{array}$ & Certificate II in Business \\
\hline Tamara (F) & $\begin{array}{l}\text { Graduate Diploma in Fine Arts } \\
\text { (1972) }\end{array}$ & $\begin{array}{l}\text { Medical Receptionist Course; } \\
\text { Diploma of Shiatsu }\end{array}$ \\
\hline $\operatorname{Dan}(\mathrm{M})$ & $\begin{array}{l}\text { Certificate II in Automotive } \\
\text { Mechanical(1976); Certificate } \\
\text { IV in TAA; Diploma of TAA; } \\
\text { Diploma of Business; Diploma } \\
\text { of Management }\end{array}$ & $\begin{array}{l}\text { Certificate IV in Occupational } \\
\text { Health and Safety; Bachelor } \\
\text { of Training }\end{array}$ \\
\hline Ellie-May (F) & Nil & Diploma of Management \\
\hline Suzanne (F) & $\begin{array}{l}\text { Certificate II in Computer } \\
\text { Skills; Certificate III in } \\
\text { Computer Skills }\end{array}$ & Certificate IV in Business \\
\hline Linda (F) & $\begin{array}{l}\text { BA in Commerce (1989); } \\
\text { Certificate IV in TESOL; } \\
\text { Certificate IV in Volunteer } \\
\text { Tutoring }\end{array}$ & $\begin{array}{l}\text { Diploma of Business and } \\
\text { Management }\end{array}$ \\
\hline
\end{tabular}


Table 2. Purposes for undertaking training and experiences while training

\begin{tabular}{|c|c|c|}
\hline Name & Purposes for training & Experiences while training \\
\hline Corinne & $\begin{array}{l}\text { Obliged to by social } \\
\text { security services - funded }\end{array}$ & $\begin{array}{l}\text { Disliked online assessment tasks } \\
\text { and large classroom group }\end{array}$ \\
\hline Kelvin & $\begin{array}{l}\text { To advance job role and } \\
\text { increase knowledge; } \\
\text { supported by government } \\
\text { employment services }\end{array}$ & $\begin{array}{l}\text { Enjoyed self-directed and some } \\
\text { classroom activities; enjoyed } \\
\text { increasing knowledge; disliked } \\
\text { online participation tasks }\end{array}$ \\
\hline Noah & $\begin{array}{l}\text { Obliged to by social } \\
\text { security services; offered } \\
\text { financial support for } \\
\text { Indigenous students }\end{array}$ & $\begin{array}{l}\text { Disliked online assessment tasks; } \\
\text { difficulties in communication with } \\
\text { some students/teachers; struggled to } \\
\text { complete courses }\end{array}$ \\
\hline Tamara & $\begin{array}{l}\text { To return to workforce and } \\
\text { for personal interest; self- } \\
\text { supporting }\end{array}$ & $\begin{array}{l}\text { Enjoyed increasing knowledge; } \\
\text { disliked large classroom group; } \\
\text { struggled with some online } \\
\text { assessment tasks }\end{array}$ \\
\hline Dan & $\begin{array}{l}\text { To advance job role and } \\
\text { increase knowledge; self- } \\
\text { supporting }\end{array}$ & $\begin{array}{l}\text { Enjoyed increasing knowledge; } \\
\text { struggled due to psychological ill- } \\
\text { health }\end{array}$ \\
\hline Ellie-May & $\begin{array}{l}\text { Obliged to by social } \\
\text { security services - funded }\end{array}$ & $\begin{array}{l}\text { Enjoyed mixed-age group; struggled } \\
\text { with online assessment tasks }\end{array}$ \\
\hline Suzanne & $\begin{array}{l}\text { Obliged to by social } \\
\text { security services- funded }\end{array}$ & $\begin{array}{l}\text { Struggled with confidence to engage } \\
\text { with higher level courses }\end{array}$ \\
\hline Linda & $\begin{array}{l}\text { Obliged to by social } \\
\text { security services- funded }\end{array}$ & $\begin{array}{l}\text { Enjoyed increasing knowledge; } \\
\text { struggled with some online } \\
\text { assessment tasks }\end{array}$ \\
\hline
\end{tabular}


Table 3. Employment status at Interview 1 and at Interview 5

\begin{tabular}{|c|c|c|c|}
\hline Name & Age & Interview 1 & Interview 5 \\
\hline Corinne (F) & 57 & Unemployed & $\begin{array}{l}\text { Teacher's aide } \\
6 \text { month contract, } 22 \text { h/wk }\end{array}$ \\
\hline Kelvin (M) & $58-59$ & $\begin{array}{l}\text { Community liaison, } \\
6 \text { month contract, } 30 \mathrm{~h} / \mathrm{wk}\end{array}$ & $\begin{array}{l}\text { Community liaison, } \\
6 \text { month contract, } 15 \mathrm{~h} / \mathrm{wk}\end{array}$ \\
\hline Noah (M) & $59-60$ & Unemployed & Unemployed \\
\hline Tamara (F) & $59-60$ & Unemployed & Unemployed \\
\hline $\operatorname{Dan}(\mathrm{M})$ & 55 & Unemployed & Unemployed \\
\hline Ellie-May (F) & 56 & Casual domestic cleaner & Unemployed \\
\hline Suzanne (F) & 55 & Part-time clerk & Unemployed \\
\hline Linda $(F)$ & 62 & Unemployed & Unemployed \\
\hline
\end{tabular}

